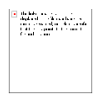

\title{
Design, Architecture and the value to tourism
}

\begin{tabular}{|c|l|}
\hline Journal: & Tourism Economics \\
\hline Manuscript ID & TEU-18-0128.R1 \\
\hline Manuscript Type: & Empirical Article \\
\hline Keywords: & Architecture, Benefits Transfer Model, Tourism, Value \\
\hline Abstract: & $\begin{array}{l}\text { Architecture has been recognized for its supporting role in the } \\
\text { enhancement of the physical assets of destinations, which play a leading } \\
\text { role in drawing tourists who identify and associate destinations with these } \\
\text { architectural landmarks. Whilst generating tourist expenditure is not the } \\
\text { aim of most architects, many are increasingly aware that articulated and } \\
\text { functional buildings become visitor attractions in their own right - an } \\
\text { externality that requires valuing. However, the value assigned to iconic } \\
\text { architecture is often restricted to the bricks and mortar construction, and } \\
\text { the broader contributions a building can deliver to its stakeholders are } \\
\text { largely ignored. This paper explores the capacity for architecture to attract } \\
\text { tourists and effect direct tourism spend through the examination of five } \\
\text { cases, each of which has attempted to estimate their economic value to } \\
\text { tourism. The paper proposes a model for estimating the future value of } \\
\text { iconic buildings, and tests it's application to the University of Technology } \\
\text { Sydney, Gehry-designed, Dr Chau Chak Wing building. The implications of } \\
\text { the framework and future research are discussed. }\end{array}$ \\
\hline
\end{tabular}




\title{
Design, Architecture and the value to tourism
}

\begin{abstract}
Architecture has been recognized for its supporting role in the enhancement of the physical assets of destinations, which play a leading role in drawing tourists who identify and associate destinations with these architectural landmarks. Whilst generating tourist expenditure is not the aim of most architects, many are increasingly aware that articulated and functional buildings become visitor attractions in their own right - an externality that requires valuing. However, the value assigned to iconic architecture is often restricted to the bricks and mortar construction, and the broader contributions a building can deliver to its stakeholders are largely ignored. This paper explores the capacity for architecture to attract tourists and effect direct tourism spend through the examination of five cases, each of which has attempted to estimate their economic value to tourism. The paper proposes a model for estimating the future value of iconic buildings, and tests its application to the University of Technology Sydney, Gehrydesigned, Dr Chau Chak Wing building. The implications of the framework and future research are discussed.
\end{abstract}

Keywords: architecture, tourism, value, benefit transfer method

\section{INTRODUCTION}

Good architecture is fundamental to economic growth and helps drive tourism and tourist spending (Guetzkow 2002). As a commodity of touristic consumption it represents objectified cultural capital (Judd 2006). According to Maitland and Newman (2008, p. 232) visitors are drawn to destinations by 'qualities of place and culture - 'architecture', 'people', 'food', 'culture' and 'diversity'”. In particular, iconic architecture (buildings, landmarks, monuments) is alluring as it typifies a place (country, city or precinct) by its "physical obtrusiveness 
demonstrating unambiguously to visitors and residents that something serious is happening to a city" (Ashworth 2008, p. 269).

Iconic architecture has been used as a centralising feature to support and drive many urban regeneration projects. Claims for the economic benefit of such projects vary, however, with the attention paid to architecture, the subsequent tourism and its boost to industry is clear (Edwards et al., 2014; Reinmuth et al., 2016; Sklair 2010). In a study of wine consumption, Laflamme (1999, p. 16) argues that architecture "adds value to both the production and sale of wines, as well as [providing] a destinational attraction”.

Perhaps one of the most well-known attractions of this nature is the Guggenheim Museum in Bilboa Spain (Vicario \& Monje 2003). It was estimated that in its first three years of operation the Guggenheim Museum helped to generate approximately \$500 million in economic activity and $\$ 100$ million in new taxes (Rybczynski 2002). The economic contribution attributed to this iconic building has given the destination naming rights to the phenomenon referred to as the "Bilbao effect" (Stevens 2017, p. 188). Such was its success that destinations globally seek to have their own iconic architecture in the hope of realising similar economic benefits (Edwards et al., 2008).

The Sydney Opera House is also exemplary in this regard and is estimated to contribute "AU\$640 million in yearly expenditure by visitors to Sydney" (Deloitte 2013, p. 1) as it attracts visitors to Sydney, who extend their stay and spend their money on a range of services, and attractions. Thus, architecture aestheticises spaces with recognisable markers that facilitate a particular sense of place. Iconic architecture 'pulls' visitors to and through precincts (Edwards, Griffin \& Hayllar 2008), and provides focal points for visitor attention and experience (Krolikowski \& Brown 2008).

Work has been undertaken to assess the value of good design in architecture, particularly in the 2000's by the Royal Institute of British Architects (RIBA) and The 
Commission for Architecture and the Built Environment (CABE), both in the United Kingdom (Edwards et al., 2014; Reinmuth et al., 2016; Sklair 2010). These studies have made important leaps in valuing good design, however there has been limited progress in determining value beyond the building cost. Where studies have ventured further in determining broader benefits, these were measured in terms of urban impact ((CABE) 2002), safety and crime rate reduction (Katyal 2002), health impacts (Dannenberg, Frunkin \& Jackson 2011), and maintenance and life-cycle costs (Krstic \& Marenjak 2012). In addition to the Sydney Opera House, further studies were found which have attempted to value the tourism contribution of architecture. However, each of the studies used a different approach to measure the contribution and all were post hoc. This paper proposes a method to address the gap in the estimation of architecture's contribution to tourism pre hoc so that a better understanding of the revenue generating capacity of architecture can be realised. Advancing such methods will enhance decision-making in relation to planning and policy.

This paper is structured in seven sections. Section 2 begins with a literature review that discusses the context of architecture in relation to tourism. Section 3 presents five previous cases that measure and articulate the value of existing architecture to tourism are presented and discussed. The case studies include: the Guggenheim Museum, (GMB) Bilbao, Spain; the Te Papa Tongarewa Museum (TPM), Wellington, New Zealand; the Sydney Opera House (SOH), Sydney, Australia; The Museum of Old and New Art (MONA), Hobart, Tasmania; and the Bendigo Art Gallery (BAC), Bendigo, Victoria. To address the inconsistencies found in the case studies an alternative method is proposed, the benefits transfer method (BTM). Section 4 presents the benefits transfer method (BTM) as the methodology. Section 5 is the methodological application of the BTM with the worked example of the method to the prohoc assessment of an emerging architectural icon, the University of Technology Sydney, Gehrydesigned, Dr Chau Chak Wing building, New South Wales, Australia. Section 6 presents the 
limitations of the study. In section 7 conclusions are drawn and recommendations for future research are made.

\section{LITERATURE REVIEW}

Architecture is narrowly perceived within the architectural services profile offered by the market research company IBIS World (Chia 2015) and other similar reports as part of the construction industry. From this perspective, the focus is on the tangible costs involved in constructing a building. Land, location, design services, building material costs and labour form the basis of the value estimate. Less tangible values such as design aesthetics are not included. As a result, the real value of design and aesthetics, and architecture's contribution to the economy are under-reported and undervalued (Reinmuth et al., 2016), ignoring the substantial economic and social contribution made by architecture through a variety of broader services.

Architecture is unique, sitting historically between the arts and the sciences, contributing to a broad ecology of products and services, linked not only to the built environment, but also a broader context of design, creativity and information. This includes (inter alia) connections to information graphics, media, industrial design, manufacturing, hard and soft technology development, human environmental health factors, environmental, cultural and economic sustainability, information architecture, publishing and other forms of cultural production, as well as contributions to the fields of planning and landscape architecture. Architecture also operates within the space of cultural production and consumption. Architects present ideas, drawings, new works, and exhibitions and increasingly create cultural events within architectural spaces that generate economic activity, while also making a broad cultural contribution. Thus, architecture must be assessed not only in terms of what is built, but how 
these constructions are used to spur socio-cultural activity and generate economic benefit in return.

Architectural assets hold both tangible (bricks and mortar) and intangible value. The intangible value of buildings exist in a variety of forms including aesthetic or image value and cultural value. Aesthetic value is achieved through the mutual contributions of identity, vision and reputation and in the ways groups, institutions, and cities express ideas, ambitions and intentions that are captured in the distinctive designs of their buildings. Cultural value creates a sense of place by connecting location, context and patterns of historical development incorporating cultural symbolism and social meaning (Hayllar, Griffin \& Edwards 2008). An examination of the architectural literature identified the Guggenheim Museum in Bilbao, the Dublin Canal Theatre, MGM Mirage in Las Vegas, Denver Art Museum, Yangi Lake Kempinski Hotel in Bejing and the Lofoten Island Opera House in Norway as all having aesthetic or image value (Stevens 2017). In Australia, the Sydney Opera House, Harbour Bridge, and Rose Seidler House among others were identified as significant architectural works because of their "iconic" value (Burke \& Macdonald 2014). Elsewhere in Sydney, the Hyde Park Barracks, Justice and Police Museum and Elizabeth Bay House all have "historic" value, while the Australian National Maritime Museum, Museum of Contemporary Art and the Powerhouse Museum all hold "cultural value". However, these values are not mutually exclusive as a building can have multiple types of values.

A central part of the tourism industry hinges on the built environment and the quality of touristic places - from heritage buildings and precincts to iconic modern buildings. In the case of Australia, this form of tourism and associated international activity, can promote a form of soft power developed through esteem - raising Australia's profile and agency abroad. As Muratovski (2012, p. 198) notes:- "architecture is in a sense a promotional medium and an identity definer. It is a medium that promotes social relationships and individual enterprises, 
and can be used as a symbol of territorial identity." The value of built-environment heritage for tourism cannot, therefore, be ignored.

Cultural events that engage with or are focused on architecture, are becoming more common and attracting increasing numbers of tourists (Carey, Davidson \& Sahli 2013; Deloitte 2013). An explosion of biennales held around the world has occurred in response to growing interest in architectural tourism, and recognition of the capacity for cultural tourism to transform cities. Currently 221 biennales occur around the world, which combine and celebrate art, architecture and design. Of these, 24 are dedicated specifically to architecture. Every other year, the Venice Architecture Biennale brings thousands of tourists to Venice to experience the four-month exhibition, with more than 178,000 people visiting in 2012 (Australian Institute of Architects, 2013). Additionally, Sydney Architecture Festival (Sydney, Australia), World Architecture Day (celebrated globally), and Vivid (Sydney, Australia) are further examples of annual events that are centred on architecture and capturing the broader public's interest in architecture as sites of experience.

As highlighted above, architecture is recognised as both contributing to cultural products and creating and enhancing built physical assets, which play leading roles in drawing tourists to a destination (Edwards et al., 2014; Sklair 2010). Significant effort has been invested into assessing the impact of tourism on national and city economies. Increasingly, the assets that support tourism, from physical environments to cultural events and attractions, are under closer scrutiny (Carey, Davidson \& Sahli 2013; Deloitte 2013). The role of 'star' architects in particular has received significant attention (Fuerst \& McAllister 2010; Ponzini 2014). The Deloitte (2013) report also identified the brand value of places and symbols. The Sydney Opera House is an excellent international example of an iconic building that has made an economic contribution over and above the costs of bricks and mortar. To create a more complete picture 
of the added value of architecture, a framework that goes beyond the building value and takes a holistic perspective of the contribution of architecture is required.

\section{PREVIOUS CASES}

Architecturally designed buildings that have been studied in terms of their ability to attract tourists include the Guggenheim Museum (GMB) (Plaza 2007), Te Papa Museum (TPM) (Carey, Davidson \& Sahli 2013), Sydney Opera House (SOH) (Deloitte 2013), Museum of New and Modern Art (MONA) and Bendigo Art Gallery (BAG) (Evans, Bridson \& Minkiewicz 2013). Table 1 presents a summary of each of the five case studies, and the method used to estimate the full value of each of the buildings. It should be noted that each of the studies was conducted for existing buildings. A number of common themes were drawn from the studies. Each showed value generated through the direct use of the building through activities such as viewing exhibitions or attending performances. In addition, non-use values such as cultural value, brand value, increased community pride and sense of belonging were determined.

Each of the studies examined the value of the architecture retrospectively. Investments in buildings and their designs are generally based on the financial data included in the business case, which are most often limited to their use value. However, each of the studies presented in Table 1 identified additional value generated through the contributions of visitor expenditure that flow through the economy boosting the overall level of incomes, employment and taxes (Guetzkow 2002; Sterngold 2004). Visitors are often attracted to a destination by the prospect of visiting multiple attractions, creating a "team production" (Alchian \& Demsetz 1972, p. 779) or "resource bundle" (Wernerfelt 1984, p. 175) effect. The TOM and SOH studies both applied a team production factor in this regard. In such situations it is difficult to assign a value to one attraction as "individual cooperating inputs do not yield identifiable separate products 
which can be summed" (Alchian \& Demsetz 1972, p. 779). Therefore, a proportion of the total visitor expenditure is assigned to individual attractions (resources) within the team. In both the Te Papa Museum and the Sydney Opera House a value of ten per cent was arbitrarily assigned as the team production factor.

Different measurement methods were used for each study. A discounted cash flow model measuring the return on investment for the Guggenheim Museum. The Input - Output Analysis (I-O) method measure income generated to different sectors of the New Zealand economy by the Te Papa Museum for the 11 years from the time the building was built in 1998 to 2009 . 
Table 1. Summary of case studies

\begin{tabular}{|c|c|c|c|c|c|c|c|c|}
\hline Building name & Location & Architect & Year & Purpose & $\begin{array}{l}\text { Building } \\
\text { cost } \\
\text { (Millions) }\end{array}$ & Measurement method & Finding & Author \\
\hline $\begin{array}{l}\text { Guggenheim } \\
\text { Museum }\end{array}$ & Bilbao, Spain & $\begin{array}{l}\text { Frank } \\
\text { Gehry }\end{array}$ & 1997 & Museum & $\begin{array}{l}\text { USD } \\
228.3\end{array}$ & Discounted cash flow model & $\begin{array}{l}\text { Return on investment in } 7 \text { years from } \\
\text { opening. } \\
\text { Served as an economic reactor }\end{array}$ & Plaza (2007) \\
\hline Te Papa Museum & Wellington, NZ & $\begin{array}{l}\text { Ivan } \\
\text { Mercep }\end{array}$ & 1998 & Museum & $\begin{array}{c}\text { NZD } \\
300\end{array}$ & $\begin{array}{l}\text { Input - Output Analysis and team } \\
\text { production factor }\end{array}$ & $\begin{array}{l}\text { Positive impact on tourism, flagship } \\
\text { status played a significant role in } \\
\text { attracting tourists }\end{array}$ & $\begin{array}{l}\text { Carey, Davidson } \\
\& \text { Sahli (2013) }\end{array}$ \\
\hline $\begin{array}{l}\text { Sydney Opera } \\
\text { House }\end{array}$ & Sydney, AU & Jorn Utzen & 1973 & $\begin{array}{l}\text { Performing } \\
\text { Arts }\end{array}$ & $\begin{array}{c}\text { AUD } \\
102\end{array}$ & $\begin{array}{l}\text { Estimate of tourism spending } \\
\text { (international, domestic day and } \\
\text { domestic overnight visitors) and } \\
\text { team production factor }\end{array}$ & $\begin{array}{l}\text { Estimated to contribute up to } \$ 640.1 \mathrm{mill} \\
\text { to Sydney economy, that is, } 10.55 \% \text { of } \\
\text { total Sydney holiday spend }\end{array}$ & Deloitte (2013) \\
\hline $\begin{array}{l}\text { Museum of Old } \\
\text { and New Art } \\
\text { (MONA) }\end{array}$ & Hobart, AU & $\begin{array}{l}\text { Nonda } \\
\text { Katsalidis }\end{array}$ & 2011 & Art Gallery & $\begin{array}{l}\mathrm{AU} \\
75\end{array}$ & $\begin{array}{l}\text { Extrapolated from tourism visitor } \\
\text { numbers and spend }\end{array}$ & $\begin{array}{l}28 \% \text { of visitors to Tasmania visit } \\
\text { MONA and } 16 \% \text { stated MONA was the } \\
\text { primary reason for visiting }\end{array}$ & $\begin{array}{l}\text { Data from } \\
\text { Tourism } \\
\text { Tasmania } \\
\end{array}$ \\
\hline $\begin{array}{l}\text { Bendigo Art } \\
\text { Gallery } \\
\text { (redevelopment) }\end{array}$ & Bendigo, AU & $\begin{array}{l}\text { Karl } \\
\text { Fender }\end{array}$ & 2014 & Art Gallery & $\begin{array}{c}\text { AUD } \\
8.5\end{array}$ & $\begin{array}{l}\text { Economic impact, community value } \\
\text { and social inclusion }\end{array}$ & $\begin{array}{l}\text { Increase in tourism and community } \\
\text { identify and community pride and } \\
\text { economic development and growth }\end{array}$ & $\begin{array}{l}\text { Evans, Bridson } \\
\text { and Minkiewicz } \\
\text { (2013) }\end{array}$ \\
\hline
\end{tabular}


The Te Papa study also showed a positive correlation with the existence of the building and guest arrivals, overnight stays and occupancy rates across three different commercial accommodation sectors: hotels, motels and backpackers (Carey et. al 2012).

Whilst a well-designed building does not guarantee financial success (Droege 1999), the post hoc assessments of the GMB and TPM both showed positive returns on investment within 7 years and 5 years respectively, from their launch. These studies were conducted ten years and fifteen years respectively after launch. The return on investment period for the GMB was 7 years, and for the TPM it was only five years. Tourism spending, shown in Figure 1, was a measure used by Deloitte (2013) as part of a comprehensive study into the value of the $\mathrm{SOH}$. Tourism Tasmania visitor reports were used to extrapolate tourism spend data generated by the MONA gallery. Economic impact, community impact, and social inclusion measures were conducted to coincide with the launch of the Bendigo Art Gallery renovation.

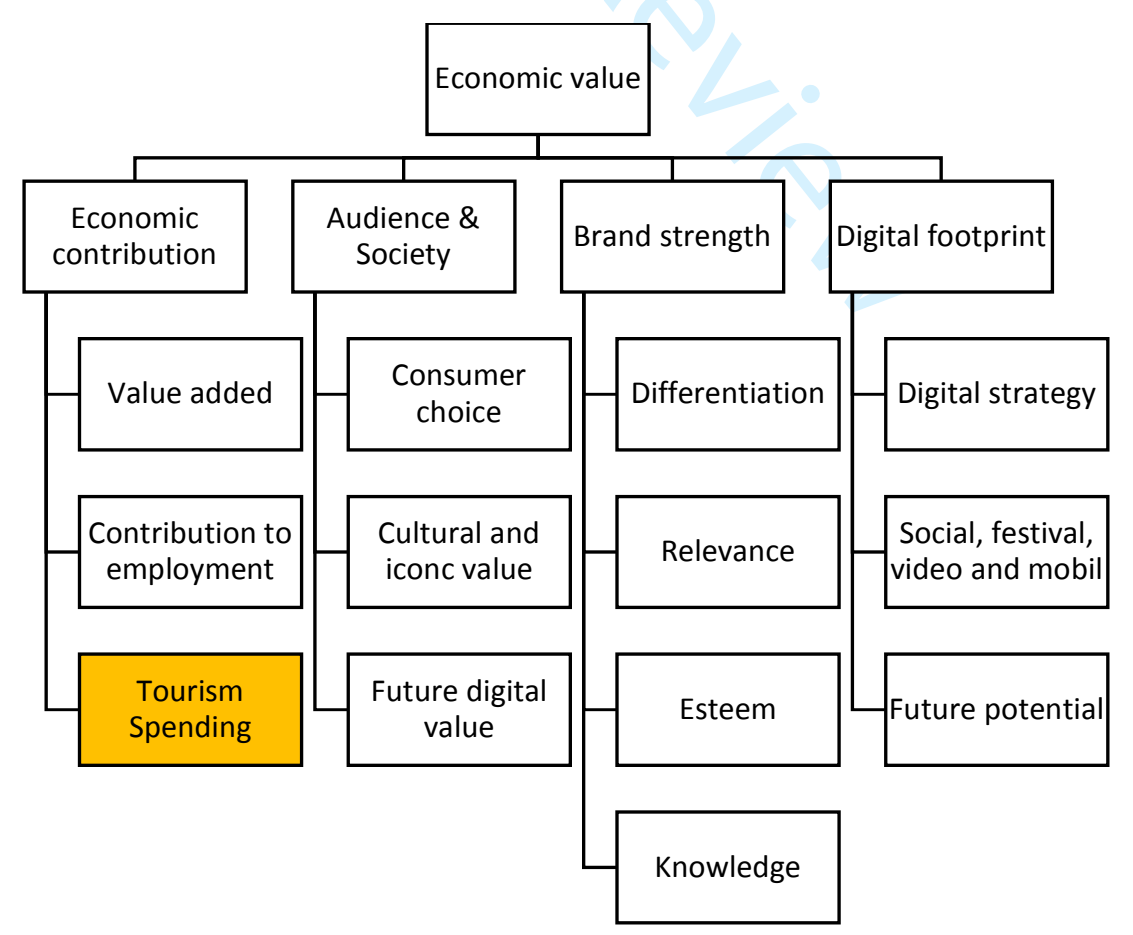


Figure 1. Scope of the Report (Deloitte, 2013, p. 3)

Two things all of the studies do have in common is (1) they were all conducted post hoc, that is after the buildings were competed and operational and (2) the measures fail to fully acknowledge the importance of such buildings to the appeal of a destination.

In this study we apply the Benefits Transfer Method (BTM), often used to estimate the value of environmental resources, allows for the estimation of value contribution, without the need to collect. The BTM in this study is used to estimate the value of the CCW building prehoc. The BTM is defined by Smith et al., (2002 ) as the “...practice of adapting value estimates from past research to assess the value of a similar, but separate, change in a different resource" (cited in Boutwell \& Westra, 2013, p.518). Johnston et al., (2015, p.19) extend the application to include "policy contexts" and Boutwell \& Westra, (2013, p.518) incorporate this extension into a refined definition where BTM "uses previously established values that were estimated for sites with similar characteristics and in similar contexts for application into existing policy decisions". Most studies using the BTM seek to estimate the value of environmental sites or sites at which visitors engage in outdoor recreation (Johnston et al., 2015; Rosenberger \& Loomis 2001) to local economies. While primary research is preferred the suitability of BTM is its practical application in the face of budgetary constraints, time limitations, and/or, where there is a paucity of available data as is often the case with new architecturally significant buildings, such as the University of Technology Sydney’s Gehry-designed, Dr Chau Chak Wing building.

\section{METHODOLOGY}

BTM enables the transfer of available information from one study to another by adapting an estimate of the benefits. According to King \& Mazzotta (2000) and Lloyd-Smith (2014) there 
are 4 steps to conducting the benefits transfer method, which are shown in Figure 2. These four steps are discussed by applying the method to an exemplar case.

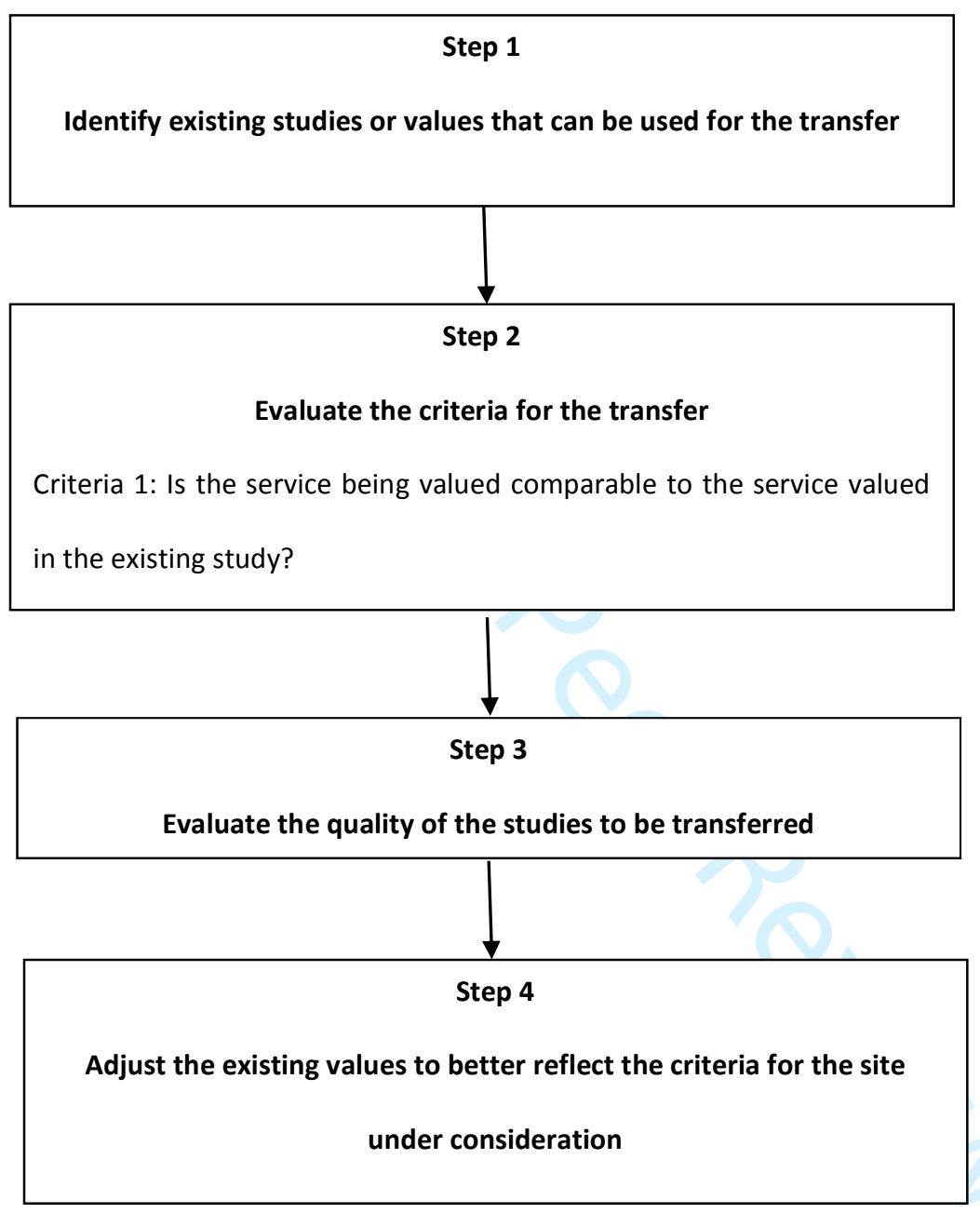

Figure 2. Four steps to conducting the benefits transfer method (King \& Mazzotta 2000;

Lloyd-Smith 2014)

Step 1 - Identify existing studies and values that can be used for the transfer

After reviewing each of the five cases, the $\mathrm{SOH}$ study was selected to be the exemplar case to be used to transfer the benefits. The $\mathrm{SOH}$ was selected because of the distinctiveness of its design (holding iconic value) and the environmental (economic, social and political) 
conditions in which it operates which are roughly equivalent to the University of Technology's Dr Chau Chak Wing building. The tourist spend in the SOH study is based upon average spend estimates for international, domestic and domestic day visitors (Deloitte 2013).

Step 2 -Evaluate the criteria for the transfer

There are two criteria to be evaluated for the validity of the Benefit Transfer Method to be verified. The first examines whether the service being valued is comparable to the service valued in the case study. The second establishes whether the characteristics of the relevant populations are comparable.

The service offered by the $\mathrm{SOH}$ is a performance space which provides people (audiences) with creative performances, which have a start time and an end time (2 to 3.5 hours in duration) and may free of charge or accessed for a fee. In addition to the performance spaces, the $\mathrm{SOH}$ has a forecourt area where visitors may observe and gain nonuse value without necessarily entering the building. The Dr Chau Chak Wing building is comparable because it provides spaces where academics and students "perform", lectures or classes as performance have a start time and an end time of similar duration and may be accessed for a fee or free of charge. The Goods Line provides users and non-users with a space to observe and gain non-use value without entering the building, hence acting as a forecourt.

In addition to visitors who attend performances, both the $\mathrm{SOH}$ and the Dr Chau Chak Wing building attract visitors who wish to explore the external and internal design of the buildings, as such these visitors have comparable characteristics. Therefore, the benefits of the population in the SOH case can be transferred to the Dr Chau Chak Wing building despite it being a newly opened building with no available data to use. Hence, the criteria for the population will be visitors whose primary purpose of travel is for leisure and who have a 
specific interest in arts, heritage or festival activities specifically and those that reported an interest in visiting history / heritage buildings, sites or monuments. This population can be further segmented into the number of international visitors, domestic overnight visitors and domestic day visitors, as it was in the $\mathrm{SOH}$ case.

Step 3 - Evaluate the quality of the study to be transferred

A report by Deloitte (2013) entitled "How do you value an icon?" The Sydney Opera House: economic, cultural and digital value" (hereafter referred to as the "Valuing the Icons' report) was designed to update previous economic contribution reports to mark the SOH's 40th year in operation and to determine the value generated from a series of building maintenance, renovation and improvement projects. The report did not evaluate any particular service or function and was not designed as a funding needs assessment or a business case for any project. Therefore, we argue, the study provides a systematic, objective and technically efficient analysis. The report provides a sound basis for applying the Transfer Benefit Method to the Dr Chau Chak Wing building.

Step 4 -Adjust the existing values to better reflect the values of the site under consideration

Step 4 is generally applied by policy makers or where studies have policy or budgetary implications. However, Ready and Navrud (2005, p.196) suggest that "in some situations it may not be desirable to adjust values to individual contexts". The question of whether to adjust existing values is addressed by Berland, Magnussen \& Navrud (2003) who identified the BTM is most often applied using an unadjusted unit approach, and that is, where the assumption is that if the sites are within a given cultural and socio-economic context the transfer of the entire value function is recommended. However, other scholars such as 
Downer and Ozuma (1996) claim the BTM is a poor predictor in some cases and Piper \& Martin acknowledge that despite improvements in the application of the BTM, the accuracy of the method remains in doubt. However, we accept Engels (2002, p. 133) underlying assumption that imperfect estimations are better than no estimations and therefore, also apply an adjusted unit value based on studies by (Bergland, Magnussen \& Navrud 2003), where the demand function was shown to be transferable and the benefit function not.

\section{Methodology Application}

A visitor attraction can be defined as a "named site with a specific human or natural feature which is the focus of visitor and management attention' (Pearce 1991, p. 46). The University of Technology Sydney Gehry-designed Dr Chau Chak Wing building (Figure 1) is a recent example of a building that can be defined in terms of its architectural distinctiveness, aesthetic appeal and attractiveness to visitors. Opened in December 2014 the Dr Chau Chak Wing building has attracted multitudes of visitors who wander to, around, and inside the building, appreciating its unique architectural form and presence. The exterior and interior of the Gehry-designed building is creative, innovative, provocative and "a space where creativity is encouraged and all ideas are welcome” (Lancione \& Clegg 2014, p. 288). 
The Dr Chau Chak Wing building has effectively changed the landscape, scale, tempo, and 'feel' of the city experience in the Haymarket precinct in which it is situated, as well as changing the type of visitor activity within it. The Dr Chau Chak Wing building has emerged as an anchor attraction, pulling visitors from the Circular Quay in the north to the Haymarket in the south. As such, the Sydney Opera House and the Dr Chau Chak Wing building demonstrate how space, people, activity and architecture interact dialectically to shape the visitor experience. It can be argued that conferences, public workshops, seminars and other presentations conducted by academics and attended by audiences at the Dr Chau Chak Wing building are similar to services offered by the $\mathrm{SOH}$.

Some have claimed that "Frank Gehry's UTS building is no Opera House", stating that it is nothing more than "a karate-chopped paper bag of undulating brickwork" (Farrelly, 2014 p.1). Despite whether the building appeals to one's sense of aesthetics or not, we do 
acknowledge that the $\mathrm{SOH}$ is not only an iconic building and a major Sydney tourist attraction, it is also recognised as a Heritage site by UNESCO and is listed on the National Trust Register (1983), the City of Sydney Heritage Inventory (2000), NSW State Heritage Register (2003), Australian National Heritage List (2005) and regarded around the world as an Australian icon. Consequently, in this study two applications of the BTM are made. The first application is an optimistic assessment where we use an unadjusted unit approach, applying the same demand (tourist visitor numbers) and benefit function $(10 \%$ team production factor) and the second application is a more pessimistic approach where we apply the same demand function (tourist visit numbers) and an adjusted benefit function (team production factor) of five percent.

As discussed previously the approach to assigning value in team production makes it difficult to attribute a value to any one tourist attraction. However, as tourism activities are an input provided in the delivery of the attraction the amount paid by visitors to participate in those activities can be used as a proxy for output. According to the Deloitte Valuing Icons report (2013), tourism activities related to the $\mathrm{SOH}$ can be defined as:

- Attending the theatre and other performances

- Visiting heritage buildings, sites, monuments or building of significance

- Sightseeing

- All other activities

The Deloitte (2013) 'Valuing Icons' report used visitor estimations derived from an International Visitor Survey (IVS) and National Visitor Survey (NVS). Thus the same approach is adopted in this research, whereby the transfer of existing values for a unit are used to value the contributions of the Dr Chau Chak Wing building. The estimate is based on two assumptions. 
The first assumption is the "return on investment" time period required for the Guggenheim (seven years) and TPM (five years) is the time taken for a building to gain a level of maturity and exposure in the market. The second assumption is that tourism visitors to the Dr Chau Chak Wing building are also categorised as those seeking to visit heritage buildings, sites, monuments or buildings of significance. The final assumption is that the team production factors for the $\mathrm{SOH}$ and the Dr Chau Chak Wing building will be comparable at approximately ten per cent. We are optimistic and accept that these assumptions hold true and for comparison take a more conservative or pessimistic approach and estimate the team production factor (benefit function) to be five percent.

\section{Data sources}

Data from Tourism Research Australia (TRA) is taken from the International Visitor Survey (IVS) and the National Visitor Survey (NVS) reported by Destination NSW in their estimation of the visitor numbers and visitor spend to destinations in Sydney and New South Wales (NSW). The segmentation of visitors are based on their main place of residence and are counted as either international, domestic overnight or domestic day visitors (see Appendix B for definitions). The IVR and NVS include questions regarding the activities undertaken during their stay (see Appendix C for Day Trip Leisure Grid) and the nature of the expenditure (see Appendix D Day Trip Expenditure Grid). Table 2 shows data extracted from the Data based on the Destination NSW Travel to Sydney Region Year ended 2017 (longitudinal data - YE Dec 2013) and the 2013 Cultural and Heritage Tourism to NSW report (Destination NSW, 2013). The number of international visitors was 2,817,700 of which $61.9 \%$ visited cultural and heritage buildings, sites and monuments and spent AU92 dollars per day. Of the $8,337,000$ domestic visitors $33.3 \%$ visited history / heritage buildings, sites or monuments in Sydney and spent AU252 dollars per day. Of the 4,100,000 day 
trippers, $25.5 \%$ visited Sydney historic/ heritage buildings, sites or monuments and spent on average AU111 dollars per day. The total spend AU976,120,575 dollars. An optimistic assessment of the value of the UTS Business School Dr Chau Chak Wing building, where the team production factor of $10 \%$ is applied, shows the building has the potential to contribute in the vicinity of AUD97.6 million to tourism within 5-10 years. However, we acknowledge that the UTS Business School Dr Chau Chak Wing has not established the same level of historic, iconic and cultural value as the $\mathrm{SOH}$ and arbitrarily apply a 'pessimistic' team production factor of $5 \%$. This effectively halves the predicted annual contribution to AUD48.8 million, this is seemingly more than if the building did not have iconic characteristics. 
Table 2 - Optimistic and pessimistic application of the BTM to the CCW building

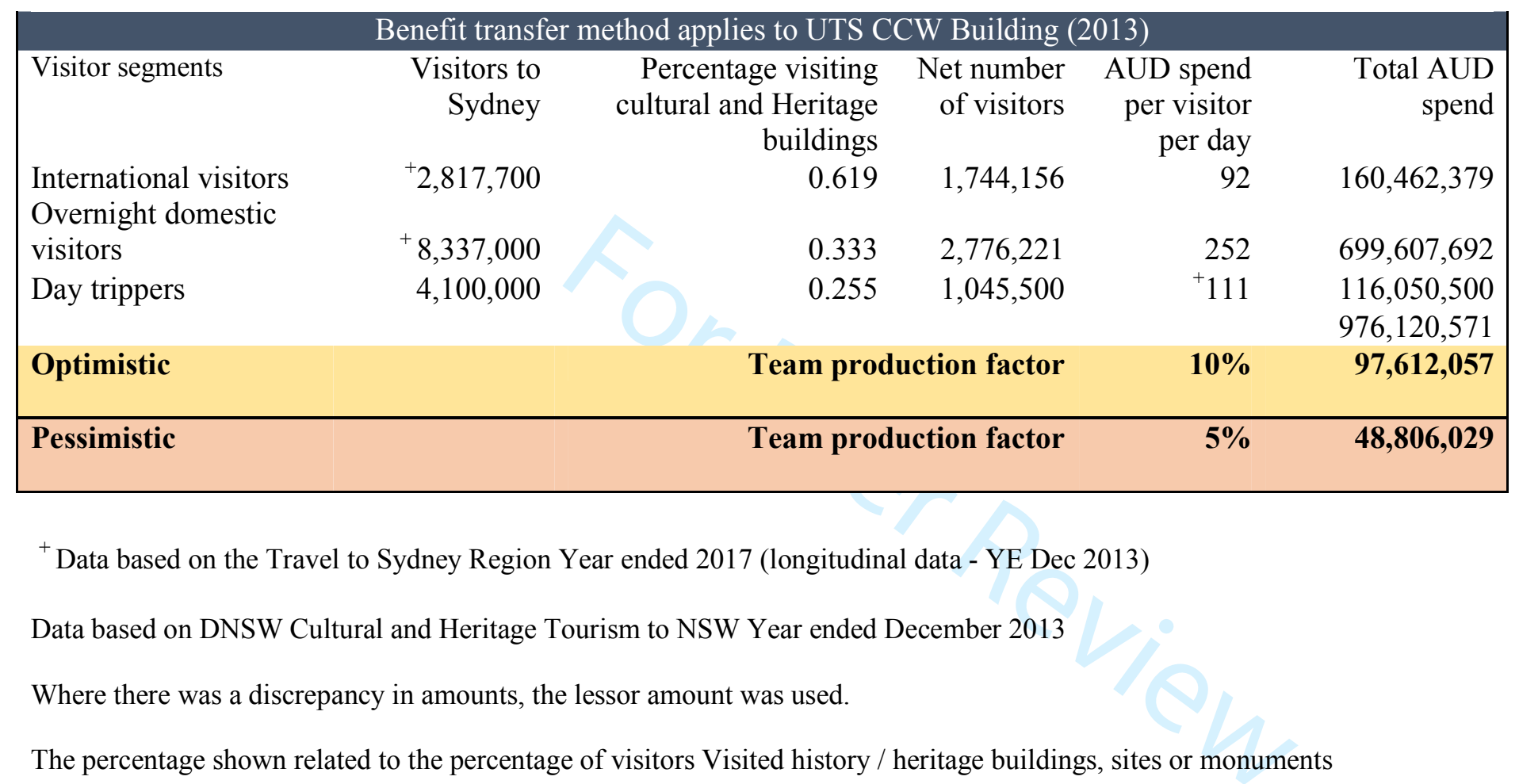




\section{LIMITATIONS OF THE STUDY}

There are four key limitations of this estimation. In cases examined in this study were all conducted post hoc. Specifically the 2013 Deloitte study of the SOH was done to coincide with celebrated 40 years of operation. The Dr Chau Chak Wing building on the other hand is done prehoc, as the $\mathrm{CCW}$ has only been operational for a fraction of that time. Thus, the transferred estimates made in this study are not directly comparable on a time scale, rather they serve as estimations of the potential future contribution to tourism. The question then becomes: over what time frame are these figures likely to accrue? As previously shown, other studies estimate that the likely time period for significant buildings to achieve a positive return on investment is between five and seven years. Therefore, the estimates made here must be considered as valuations of future potential limited to 2013 market conditions and data. Expected tourism growth figures are not included in the study despite the estimations representing a projected value.

Two team production factors were applied in this study. The first was an optimistic approach where a direct unit value transfer of $10 \%$ team production factor (as was used in the Deloitte (2013) study of the SOH) A pessimistic approach applying a team production factor of $5 \%$ was also applied. This recognised the historic, cultural and iconic value of the $\mathrm{SOH}$. However, other factors may affect the team production factor have not been studied and remain an area of future research. Factors such as location and the primary purpose of the building are two key variances which are likely to have a positive or negative effect on the ability of the building to contribute to the team. For example, the $\mathrm{SOH}$ is located in an idyllic location on Sydney Harbour, surrounded by open space, and with views of the Sydney Harbour Bridge. It is also one of the gateways into the Sydney Botanical Gardens and is within easy walking distance to the Art Gallery of New South Wales, the Museum of 
Contemporary Art and The Rocks historic precinct. The SOH also holds one-off events that attract crowds, rather than audiences (for example, the Sydney New Year's Eve celebrations).

The Dr Chau Chak Wing building, on the other hand, is located in a creative education precinct and surrounded by narrow streets on three sides and by the newly opened Goods Line on the fourth. The Goods Line is open public space and serves as a forecourt to the Dr Chau Chak Wing building connecting people to other attractions such as the Powerhouse Museum, International Convention Centre Sydney (conference and entertainment centre facilities) and the tourist precinct of Darling Harbour. The area is still undergoing significant change and the effects these changes may have on the Dr Chau Chak Wing building's contribution to team production are difficult to estimate.

The functional attributes of the building were not taken into consideration in this study, other than to draw upon similarities between the activities associated with the Dr Chau Chak Wing building and those of the SOH. As previously mentioned, performances held in the $\mathrm{SOH}$ were likened to the academic performances held in the UTS-BS building, the similarity between the two are based on the fact that both styles of performances engage the minds of their respective audiences. Both higher education and the higher arts play a role in the community as merit goods - on the grounds that they generate an enlightened and educated citizenry (Bakhshi, Cunningham \& Mateos-Garcia 2015). This assumption needs to be tested because other functional aspects such as performance capacity, seating capacity, timing and scheduling of performances, and variances in audience demographics have not been addressed. It is not clear what impact these functional and operational aspects of the building will contribute to the future capacity and development of the Dr Chau Chak Wing building and its potential to attract and service audiences.

\section{CONCLUSIONS}


Architecture captures and enhances the special local characteristics of place through unique design qualities that tourists are attracted to consume. While generating tourist expenditure is not always their explicit objective, architects, city officials and cultural organisations are increasingly aware that architecture is a visitor attraction in its own right - an externality that requires valuing. A contribution of this research to the literature is the application of the benefits transfer model to estimate the potential value of a uniquely designed building. Other estimates have calculated the benefits of iconic and significant buildings, years after they have been established. Estimating the value prior to, or in the early stages of the operation of the building enables stakeholders to better understand the economic potential of design driven development, and may facilitate conversations, cross-industry collaboration and further investment in neighbouring precincts in order to better realise direct and indirect benefits.

Attempts to estimate the contribution to tourism of significant buildings is an expensive and time-consuming process, yet the information can inform budgets, determine return on investment, establish time frames and the contributions governments at all levels are willing to make in the design component of buildings that have the potential to "pull" visitors to an area. The use of the BTM is one way to make estimates that draw on existing cases and data. The Gehry-designed Dr Chau Chak Wing building was used to demonstrate the use of a new method of valuing iconic architecture within tourism. The study applied both an optimistic and pessimistic assessment of the future value of the CCW building to tourism, with potential annual contributions being within the vicinity of AUD97.6million and AUD48.8 million respectively.

If the Dr Chau Chak Wing building is worth somewhere between AUD48.8 to AUD97.6 million to the economy annually as a base line, it is also possible to assume that other significant buildings in the same or other cities create a "bundle" effect. The Museum of Old and New Art (MONA) has been described as the most important cultural facility in 
Australian since the opening of the Sydney Opera House. It has achieved international recognition for its architectural presence, for innovating how art is experienced, and for generating economic benefits that can create a platform for significant and sustainable urban regeneration and tourism. In addition to MONA and the SOH, Australia is home to other modern iconic buildings, including One Central Park (Sydney, Australia) and Federation Square (Melbourne, Australia) which signal the presence of a strong multiplier effect in this area of economic contribution.

Government and institutions can maximise the economic benefits of the built environment vis-a-vis tourism by making available more architectural assets available to the public and strategising around bundles of mutually supporting attractors. The implications for city attractions policies, incentives for design driven development and clear branding and messaging for the tourism industry are clear.

Three areas have been identified for further study. Firstly, a full study on buildings of significant architecture needs to be conducted. In this study the visitor expenditure for the Dr Chau Chak Wing building was estimated based on visitors' primary purpose of travel being cultural and heritage tourism. An optimistic and pessimistic approach to estimating the value was used. It would be wise for future studies to be conducted to validate the estimates, estimate and identify potential causes for variance, shedding insights into the usefulness of the BTM to be used in prehoc estimation studies.

Secondly, the Dr Chau Chak Wing building's ability to attract conferences, business events and multi-day workshops suggests that a different set of variables may be required to more accurately estimate the true value of the Dr Chau Chak Wing building to tourism and tourism expenditure. Therefore, it is recommended that the tourism expenditure component be extended to include the direct expenditure method for business events proposed by Edwards, Foley, Schlenker \& Hergesell (2014). Extending the study using this method will 
provide new insights into the different kinds of activities that occur within buildings of significant architecture, and the likely impact these various activities have on tourism and tourist expenditure.

A third study could conduct research specifically into the "team contributions" of various significant architecture types and tourist attractions. A study of this nature would provide a better understanding of the characteristics of different architectural types (such as iconic architecture, landmarks, monuments, historic houses, zoos, and other categories of tourist attraction). For example, most studies conducted and cases examined include buildings where the primary purpose is arts and culture (museums). There is an absence of studies into the variances in contributions of different types of architecture or tourist attractions. It is expected that a study of this nature will classify architecture and other tourist attractions into a tiered structure according to their characteristics and their contribution to tourism in general and tourism expenditure specifically. 


\section{APPENDICES}

APPENDIX A - SUMMARY OF CASE STUDIES

CASE STUDY - Guggenheim Museum Bilbao (GMB)

\section{Background}

Designed by Frank Gehry the GMB was built in the 1990's as a means to address a number of economic and social problems in the city of Bilboa, including high unemployment rates, obsolete industries, severe traffic congestion, violence of, urban deterioration, pollution and a poor public transport system.

\section{Method of measurement}

A discounted cash flow measure was used to estimate the investment recovery period. Consequently, all economic activity generated by the museum was tracked and an assessment made on whether the income generated was greater than the initial and continuing public investment. The discounted cash flow method is limited as it measures the yield of net cash flow only and fails to capture intangible values such as aesthetic or cultural values. The return on investment for the building (excluding the initial purchase of permanent art collection) was recovered seven years after the opening. The tourism value was described simply as the annual number of new overnight stays $(777,028)$ and new full time jobs $(907)$.

\section{Outcome}

The construction of the GMB was part of a holistic plan to rejuvenate the city. The benefits to the city delivered unexpected results, as Plaza $(2007$, p.2) "the museum has brought hope to 
citizens and city officials and has united political parties, trade unions and civic associations...". Thus, the GMB is viewed as an economic reactivator, creating the phenomenon now termed the Bilbao effect. 
CASE STUDY - Te Papa Tongarewa Museum (TPM)

\section{Background}

Built in the late 1990's the TPM is an iconic waterfront building in Wellington. According to Market Economics (2012), in an economic impact assessment of TPM to Wellington city, the museum makes a significant contribution to both Wellington's and national economies through tourism employment and direct and indirect expenditure.

\section{Method of Measurement}

Input-output (I-O) analysis was used as the analytical framework with estimations conducted at the local, regional and national levels. The direct tourism spend of visitors to Wellington was used as the basis for estimating the economic impact.

The economic impact assessment indicates the significance of the TPM at three levels of the New Zealand economy. However, what has not been not measured are the intangible benefits that New Zealanders gain from the museum being "a forum where all New Zealanders can engage with their history, national pride and identity" (Carey, Davidson \& Sahli 2013 p.3)

\section{Outcome}

In cases where visitors stated that the main purpose of their visit to Wellington was to visit the TPM, $100 \%$ of the expenditure was attributed to TPM; where TPM was only one of a number of reasons for visitation, $10 \%$ of the spend was attributed at most. A challenge with examining the economic contribution of one tourist attraction is that visitors are often attracted to a destination by multiple attractions, creating a "team production" or "resource bundle" situation. As such, it is difficult to assign value to one attraction because "individual 
cooperating inputs do not yield identifiable separate products which can be summed" (Alchian and Demsetz, 1972 p.779). 
CASE STUDY - Sydney Opera House (SOH)

\section{Background}

The SOH is a key feature of the Sydney landscape, which according to Deloitte (2013), attracted nearly 1.4 million people to more than 1,800 performances.

\section{Method of measurement}

Total economic value was assessed in four key areas (1) economic factors including value added, contribution to employment, and contribution of tourist spend; (2) audience and culture, including consumer choice, cultural and iconic contributions, and future digital value; (3) brand strength attributed through intangibles such as differentiation, relevance, esteem and knowledge, and (4) digital footprint including the $\mathrm{SOH}$ digital strategy, across various platforms, including social media, video and mobile, and the future potential of streaming live performances to a world-wide audience.

The input-output approach was used to measure the economic impact attributable to tourism. Detailed calculations were provided which showed general expenditure categories to include performing arts companies, ticketing revenue, government grants, sponsorships and donations. Categories associated with direct and indirect tourism expenditure categories included a proportion of ticket sales, and expenditure on travel, food, beverages and accommodation incurred as a result of attending a performance. In addition non-use values were captured for those who visited the SOH precinct but did not attend a performance.

\section{Outcome}

The estimated tourism expenditure attributable to the $\mathrm{SOH}$ was based on visitors whose main reason for travelling to Sydney was for holiday (holiday makers), who could be separated 
into the categories of international overnight visitors, domestic overnight visitors and domestic day visitors. Based on this, the estimated contribution of the $\mathrm{SOH}$ to tourism expenditure in Sydney for 2012-2013 was estimated to be AUD \$640.1 million, this being approximately $10 \%$ of the total Sydney holiday expenditure. 
CASE STUDY - Museum of Old and New Art (MONA)

\section{Background}

Award winning MONA has been described as the most important cultural facility in recent Australian history since the opening of the $\mathrm{SOH}$. It has achieved international recognition for its architectural presence, for innovation in terms of how art is experienced and for generating economic benefits that can create a platform for significant and sustainable urban regeneration and tourism. The MONA has been headlined as "world class, helping MONA to smash Tassie's Tourism Record" (Martin 2014 p.1).

\section{Method of measurement}

Changes in visitation patterns were used to determine MONA's contribution to the Tasmanian economy by comparing visitation data before and after the opening.

\section{Outcome}

Data from the 2014 Tasmanian Tourism Survey show that $28 \%$ of tourists to Tasmania in 2014 visited MONA, an increase of $3 \%$ on the previous year. Of these visitors $66 \%$ were holiday makers, $20 \%$ were visiting friends and relatives and $14 \%$ were business travellers. Importantly, $16 \%$ of visitors to MONA stated that visiting MONA as their primary reason for travelling to Tasmania. 
CASE STUDY - Bendigo Art Centre (BAC)

\section{Background}

The importance of the BAG to Bendigo is captured in the statement "I think if you don't have an art gallery you might not have a city" (Evans, Bridson \& Minkiewicz 2013 p.4).

\section{Method of measurement}

The Asia Pacific Social Impact Leadership Centre (2013) examined the economic and social impact of regional art galleries in regional Victoria, the $\mathrm{BAC}$ being one. While the architectural elements were not mentioned specifically, or the benefits quantitatively presented, the functional purpose of the buildings was expressed in terms of the significance of the benefits and outcomes.

\section{Outcome}

Benefits attributed to the existence of the facilities include community identity and civic pride, regional development, economic growth and intrinsic impact. The triadic connection between the gallery, tourism and economic development was made clear: "the increase in tourism (as a result of the gallery) has been a major source of economic growth" (Evans, Bridson \& Minkiewicz 2013 p.4). 
APPENDIX B - VISITOR DEFINITION (TRA 2014)

\begin{tabular}{|l|l|l|}
\hline International visitors & Domestic overnight visitors & Domestic day visitors \\
\hline $\begin{array}{l}\text { Short term overseas visitors } \\
\text { to Australia for a period of } \\
\text { less than } 12 \text { months, aged } 15 \\
\text { years of above }\end{array}$ & $\begin{array}{l}\text { Domestic visitors aged 15 years } \\
\text { or more who undertake trips that } \\
\text { involve a stay away from home } \\
\text { of at least one night, but less than } \\
\text { one year, at a place at least } 40 \\
\text { kilometres from home }\end{array}$ & $\begin{array}{l}\text { Visitors are aged 15 years or } \\
\text { more who travel round trip } \\
\text { distance of at least 50kms } \\
\text { away and area away from their } \\
\text { home for at least four hours } \\
\text { and do not spend a night away } \\
\text { from their home as part of the } \\
\text { same trip. Same day travel as } \\
\text { part of overnight and } \\
\text { international travel is excluded, } \\
\text { as is routine travel such as } \\
\text { commuting. }\end{array}$ \\
& & \\
& &
\end{tabular}




\section{APPENDIX C-DAY TRIP LEISURE GRID (NATIONAL VISITOR SURVEY 2014)}

\begin{tabular}{|c|c|c|c|c|}
\hline $\begin{array}{l}\text { Outdoor or nature } \\
\text { activities }\end{array}$ & $\begin{array}{l}\text { Sports or active outdoor } \\
\text { activities }\end{array}$ & $\begin{array}{l}\text { Arts, heritage or festival } \\
\text { activities }\end{array}$ & $\begin{array}{l}\text { Local attractions or tourist } \\
\text { activities }\end{array}$ & $\begin{array}{l}\text { Anything else, such as } \\
\text { social activities }\end{array}$ \\
\hline $\begin{array}{ll}\text { - } & \text { Go to the beach } \\
\text { - } & \text { Visit national parks and } \\
\text { state parks } \\
\text { - } & \text { Go bush walking, or on } \\
\text { rainforest walks } \\
\text { - } & \text { Visit botanical or other } \\
\text { gardens } \\
\text { - } & \text { Go whale / dolphin } \\
\text { watching (in the ocean) } \\
\text { - } & \text { Visit farms } \\
\text { - } & \text { Visit the reef }\end{array}$ & $\begin{array}{ll}\text { - } & \text { Go scuba diving } \\
\text { - } & \text { Go snorkeling } \\
\text { - } & \text { Do surfing } \\
& \text { Do any water activities / } \\
& \text { windsurfing, kayaking, } \\
& \text { water skiing, white } \\
& \text { water rafting } \\
\text { - } & \text { Go fishing } \\
\text { - } & \text { Play golf } \\
\text { - } & \text { Play other sports } \\
\text { - } & \text { Do any other outdoor } \\
\text { activities (e.g. horse } \\
\text { riding, rock climbing, } \\
\text { bungee jumping, four } \\
\text { wheel driving, reef } \\
\text { walking etc) } \\
\text { - Exercise, gym, } \\
\text { swimming at a local } \\
\text { pool, river or creek } \\
\text { - } \text { Go cycling } \\
\text { - Go snow skiing }\end{array}$ & 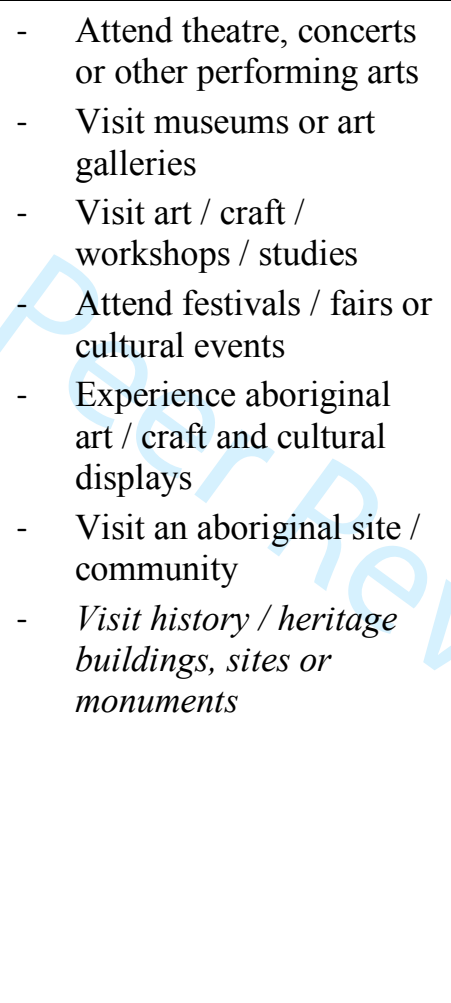 & $\begin{array}{ll}\text { - } & \text { Visit amusement parks / } \\
\text { theme parks } \\
\text { - } & \text { Visit wild life parks / } \\
\text { zoos / aquariums } \\
\text { - } \quad \text { Go on guided tours or } \\
\text { excursions } \\
\text { - } \quad \text { Go to markets (street / } \\
\text { weekend / art / craft } \\
\text { markets) } \\
\text { - } \quad \text { Go on tourist trains } \\
\text { - } \quad \text { Visit industrial tourism } \\
\text { attractions (eg } \\
\text { breweries, mines) } \\
\text { - Visit wineries } \\
\text { - Visit a health spa or } \\
\text { sanctuary / wellbeing } \\
\text { centre } \\
\text { - Visit or stay on an island } \\
\text { - Go on a charter boat / } \\
\text { cruise or ferry ride }\end{array}$ & $\begin{array}{ll}\text { - } & \text { Visit friends and } \\
& \text { relatives } \\
\text { - } & \text { Eat out at restaurants } \\
\text { - } & \text { Movies / videos (not at a } \\
\text { cinema) } \\
\text { - } & \text { Go to pubs, clubs, night } \\
\text { clubs } \\
\text { - } & \text { Visit casinos } \\
\text { - } & \text { Attend an organized } \\
\text { event } & \text { - Go shopping (for } \\
\text { pleasure) } \\
\text { - Walk or drive around } \\
\text { taking in the sights / } \\
\text { general sightseeing } \\
\text { - Go on a day trip to } \\
\text { another place (for } \\
\text { overnight visitors only) } \\
\text { - Go on picnics / BBQ's } \\
\text { - Attend movies / cinema }\end{array}$ \\
\hline
\end{tabular}




\section{APPENDIX D - DAYTRIP EXPENDITURE GRID (NATIONAL VISITOR}

\section{SURVEY 2014)}

\begin{tabular}{|l|l|l|l|l|}
\hline Expenditure & $\begin{array}{l}\text { Paid by } \\
\text { (during } \\
\text { trip) }\end{array}$ & $\begin{array}{l}\text { Paid by } \\
\text { (befor } \\
\text { trip) }\end{array}$ & $\begin{array}{l}\text { Paid by } \\
\text { (after } \\
\text { trip) }\end{array}$ & $\begin{array}{l}\text { Paid by others not } \\
\text { travelling with } \\
\text { respondent }\end{array}$ \\
\hline Package (e.g. transport + show) & & & & \\
\hline Taxis (including to / from airport) & & & & \\
\hline Airline fares & & & & \\
\hline Organized tours / side trips & & & & \\
\hline Car hire costs (rental, leasing) & & & & \\
\hline Fuel (petrol, diesel) & & & & \\
\hline Vehicle maintenance costs & & & & \\
\hline $\begin{array}{l}\text { Other long distance transport costs } \\
\text { train, coach, ship etc) }\end{array}$ & & & & \\
\hline $\begin{array}{l}\text { Other local transport costs } \\
\text { (bus, train, tram, ferry etc) }\end{array}$ & & & & \\
\hline Takeaways and restaurant meals & & & & \\
\hline Groceries etc for self-catering & & & & \\
\hline $\begin{array}{l}\text { Drinks alcohol } \\
\text { (not already reported with food above) }\end{array}$ & & & & \\
\hline Shopping, gifts, souvenirs & & & & \\
\hline Entertainment, museums, movies, zoos etc & & & & \\
\hline Horse racing, gambling, casinos & & & & \\
\hline $\begin{array}{l}\text { Convention / Conferences / Seminar / Trade Fair / } \\
\text { Exhibition registration fees }\end{array}$ & & & & \\
\hline Education, course fees & & & & \\
\hline \hline $\begin{array}{l}\text { Purchase of motor vehicles or other major } \\
\text { equipment }\end{array}$ & & & & \\
\hline $\begin{array}{l}\text { Other } \\
\text { phone, postage, medical expenses, repairs, dry } \\
\text { cleaning etc) }\end{array}$ & & & & \\
\hline
\end{tabular}




\section{REFERENCES}

(CABE), C.f.A.t.B.E. 2002, The Value of Good Design: How Buildings and Spaces Create Economic and Social Value.

Alchian, A. \& Demsetz, H. 1972, 'Production, information costs and economic organisation', The American Economic Review, vol. 62, no. 5, pp. 777-95.

Ashworth, G. (ed.) 2008, Grote Market Groningen: The re-heritization of the public realm, Elsevier Limited, Oxford, UK.

Bakhshi, H., Cunningham, S. \& Mateos-Garcia, J. 2015, 'Public policy for the creative industries', in C. Jones, M. Lorenzen \& J. Sapsed (eds), The Oxford Handbook of Creative Industries, Oxford University Press, Oxford, pp. 465-79.

Bergland, O., Magnussen, K. \& Navrud, S. 2003, 'Benefit transfer: Testing for accuracy and reliability', in R. Florax, P. Nijkamp \& K. Willis (eds), Comparative Environmental Economic Assessment, Edward Elgar, Cheltenham.

Burke, S. \& Macdonald, S. 2014, 'Creativity and Conservation: Managing Significance at the Sydney Opera House', Journal of Preservation Technoogy, vol. 45, pp. 2-3.

Carey, S., Davidson, L. \& Sahli, M. 2013, 'Capital City Museums and Tourism Flows: an Empirical Study of the Museum of New Zealand Te Papa Tongarewa: Capital City Museums and Tourism Flows', International Journal of Tourism Research, vol. 15, no. 6, pp. 554-69.

Chia, S. 2015, M6921 Architectural Services in Australia.

Dannenberg, A., Frunkin, H. \& Jackson, R. 2011, Making Healthy Places: Designing and Builging for Health, Well-being and Sustainability, vol. 1 - 417, Island Press, Washington DC, USA.

Deloitte 2013, How do you value an icon? The Sydney Opera House: economic, cultural and digital value, Sydney, Australia.

Droege, P. 1999, 'The design dividend', Property Council of Australia, Sydney.

Edwards, D., Foley, C., Dwyer, L., Schlenker, K. \& Hergesell, A. 2014, 'Evaluating the Economic Contribution of a Large Indoor Entertainment Venue: An Inscope Expenditure Study', Event Management, vol. 18, no. 4, pp. 407-20.

Edwards, D., Griffin, T. \& Hayllar, B. 2008, 'Urban Tourism Precincts: An overview of key themes and issues', in B. Hayllar, T. Griffin \& D. Edwards (eds), City Spaces Tourism Places: Urban Tourism Precincts, Elsevier, Oxford, UK, pp. 1-381.

Engel, S. 2002, 'Benefit function transfer versus meta-analysis as policy-making tools: a comparision', in R. Florax, P. Nijkamp \& K. Willis (eds), Comparative Environmental Economic Assessment, Edward Elgar Publishing Cheltenham.

Evans, J., Bridson, K. \& Minkiewicz, J. 2013, Branding the Arts: Demonstrating Imact Four Case Studies of Public Art Museums, Melbourne Business School.

Fuerst, F. \& McAllister, P. 2010, 'Green noise or green value? Measuring the effects of environmental certification on office values', Real Estate Economics, vol. 39, no. 1, pp. 45-69.

Guetzkow, J. 2002, How the arts impact communities: An introduction to the literature on arts impact studies, Centre for Arts and Cultural Policy Studies, Princetown, USA.

Hayllar, B., Griffin, T. \& Edwards, D. 2008, 'Urban Tourism Precincts: Engaging with the Field', in B. Hayllar, T. Griffin \& D. Edwards (eds), City Spaces - Tourism Places: Urban Tourism Precincts, Elsevier, Oxford, UK, pp. 1-381.

Johnston, R., Rolfe, J., Rosenberger, R. \& Brouwer, R. 2015, 'Introduction to Benefit Transfer Methods', in R. Johnston, J. Rolfe, R. Rosenberger \& R. Brouwer (eds), 
Benefit Transfer of Environmental and Resource Values. A guide for researchers and practicioners, Springer, Dordrecht. Netherlands, pp. 1-540.

Judd, D. 2006, 'Tracing the commodity chain of global toruism', Tourism Geographies, vol. 8 , no. 4 , pp. 323-36.

Katyal, N. 2002, 'Architecture as crime control', The Yale Law Journal, vol. 111, no. 5, pp. $1039-139$.

King, D. \& Mazzotta, M. 2000, Benefits Transfer Method, University of Maryland, Maryland, DC USA, viewed 12 January 2018 2018, $<$ http://www.ecosystemvaluation.org/benefit transfer.htm $>$.

Krolikowski, C. \& Brown, G. 2008, 'The structure and form of urban tourism precincts: Setting the stage for tourist performances', in B. Hayllar, T. Griffin \& D. Edwards (eds), City Spaces and Tourist Places - Urban Tourism Precincts, Elsevier Limited, Oxford, UK, pp. 1-381.

Krstic, H. \& Marenjak, S. 2012, 'Impications of design deficiency on buiding ', Gradevinar, vol. 4, pp. 1-11.

Laflamme, E. 1999, 'Architecture as tourist attraction - Broadening the concept of 'Terrior' as a design methodology', Master thesis, The University of Calgary, Calgary, CA.

Lancione, M. \& Clegg, S. 2014, 'The lightness of management learning', Management Learning, pp. 1-19.

Lloyd-Smith, P. 2014, Benefit Transfer: methods and best practices, University of Alberta, Edmonton, Canada.

Maitland, R. \& Newman, P. 2008, 'Visitor-Host Relationships: Conviviality Between Visitors and Host Communities', in B. Hayllar, T. Griffin \& D. Edwards (eds), City Spaces - Tourist Places: Urban Tourism Precincts, Elsevier Limited, Oxford, UK, pp. $1-381$.

Muratovski, G. 2012, 'The role of architecture and integrated design in city branding', Place Branding and Public Diplomacy, vol. 8, pp. 195-207.

Pearce, P. 1991, 'Analysing tourist attractions', Journal of Tourism Studies, vol. 2, no. 1, pp. 46-55.

Plaza, B. 2007, 'The Bilbao effect (Guggenheim Museum Bilbao)', MUSEUM News, vol. 86, no. 5 , pp. 1-7.

Ponzini, D. 2014, 'The values of starchitecture: Commodification of architectural design in contemporary cities', Organizational Aesthetics, vol. 3, no. 1, pp. 10-8.

Reinmuth, G., Horton, T., Burke, A., Edwards, D., Foley, C., Scerri, M. \& Horn, Z. 2016, Measuring Up: Innovation and the value add of architecture, NSW Architects Registration Board Sydney, Australia.

Rosenberger, R. \& Loomis, J. 2001, Benefit transfer of outdoor recreation use values: A technical document supporting the Forest Service Strategic Plan (2000 revision), Rocky Mountain Research Station, Fort Collins, CO, USA, Gen. Tech. Rep. RMRSGTR-72.

Rybczynski, W. 2002, 'The Bilbao Effectt', The Atlantic, vol. September issue.

Sklair, L. 2010, 'Iconic architecture and the culture-ideology of consumerism', Theory, Culture and Society, vol. 27, no. 5, pp. 135-59.

Sterngold, A. 2004, 'Do economic impact studies misrepresent the benefits of arts and cultural institutions?', The Journal of Arts Management, vol. 11, no. 2, pp. 56-70.

Stevens, T. 2017, 'Build and they will come', Placemaking: Attractions and tourism are inextricably linked, and architects play a vital role, vol. 1, CLADBook, London, UK, pp. 187-99. 
Vicario, L. \& Monje, M. 2003, 'Another 'Guggenheim Effect'? The generation of a potentially gentrifiable neighbourhood in Bilbao', Urban Studies, vol. 40, no. 12, pp. 2383-400.

Wernerfelt, B. 1984, 'A resource-based view of the firm', Strategic Management Journal vol. 5, no. 2, pp. 171-80.

Smith, V.K.; van Houtven, G.; Pattanayak, S.K. Benefit transfer via preference calibration:

'Prudential algebra' for policy. Land Econ. 2002, 78, 132-152 


\title{
Design, Architecture and the value to tourism
}

\begin{abstract}
Architecture has been recognized for its supporting role in the enhancement of the physical assets of destinations, which play a leading role in drawing tourists who identify and associate destinations with these architectural landmarks. Whilst generating tourist expenditure is not the aim of most architects, many are increasingly aware that articulated and functional buildings become visitor attractions in their own right - an externality that requires valuing. However, the value assigned to iconic architecture is often restricted to the bricks and mortar construction, and the broader contributions a building can deliver to its stakeholders are largely ignored. This paper explores the capacity for architecture to attract tourists and effect direct tourism spend through the examination of five cases, each of which has attempted to estimate their economic value to tourism. The paper proposes a model for estimating the future value of iconic buildings, and tests it's application to the University of Technology Sydney, Gehry-designed, Dr Chau Chak Wing building. The implications of the framework and future research are discussed.
\end{abstract}

Keywords: architecture, tourism, value, benefit transfer method 